University of Nebraska - Lincoln

DigitalCommons@University of Nebraska - Lincoln

H. W. Manter Laboratory Library Materials

$9-1925$

Some Marine Fish Trematodes of Maine

Harold W. Manter

University of Illinois

Follow this and additional works at: https://digitalcommons.unl.edu/manterlibrary

Part of the Parasitology Commons

Manter, Harold W., "Some Marine Fish Trematodes of Maine" (1925). H. W. Manter Laboratory Library Materials. 18.

https://digitalcommons.unl.edu/manterlibrary/18

This Article is brought to you for free and open access by DigitalCommons@University of Nebraska - Lincoln. It has been accepted for inclusion in H. W. Manter Laboratory Library Materials by an authorized administrator of DigitalCommons@University of Nebraska - Lincoln. 


\section{SOME MARINE FISH TREMATODES OF MAINE*}

\section{Harold W. Manter}

During the summer of 1924 a study of marine fish parasites was made at the Mount Desert Island (Me.) Biological Laboratory. The present paper represents a preliminary report on the trematode group. Three new species of trematodes are described. Only brief consideration is here given to species already known. A later paper will deal more completely with these and related forms. The writer is indebted to Dr. H. B. Ward under whose direction the studies were undertaken. Gratitude is also expressed to Prof. Ulric Dahlgren for many courtesies received at the Mount Desert Island Biological Laboratory.

\section{Podocotyle atomon (Rud. 1802)}

From intestine, Pholis gunnellus (Butterfish), Anarrhichas lupus (Wolf-fish).

The forms described by Stafford (1904) and Cooper (1915) as Sinistroporus simplex can doubtless be referred to either $P$. atomon or $P$. olssoni. The chief distinctions between the two species are the longer esophagus, smaller testes, and continuous vitellaria of $P$. atomon. One specimen of this species was taken from each of two butterfish of ten examined.

\section{Podocotyle olssoni Odhner 1905}

From intestine, Urophycis tenuis (Hake), Myxocephalus groenlandicus ? (Sculpin) Gadus callarias (Cod).

These forms are apparently identical with the Dist. simplex of Linton (1898: 525).

3. Stephanochasmus baccatus Nicoll 1907

From intestine, Hippoglossus hippoglossus (Halibut).

This trematode agrees very well with the description of Nicoll (1913 a).

\section{Lepidapedon rachion (Cobb.) 1858}

From intestine, Melanogrammus aeglifinus (Haddock).

These trematodes are found only in very small numbers (one to three) in a single host. Odhner's (1905) extensive description of Lepidora rachiaea furnishes complete morphological data on the species.

\section{Lepidapedon elongatum (Lebour 1908)}

From intestine, Urophycis tenuis (Hake).

Five specimens were collected from a single host. They differ from Miss Lebour's (1908) description in not being more elongate than $L$.

* Contributions from the Zoological Laboratory of the University of Illinois, under the direction of Henry B. Ward, No. 265. 
rachion. An average sized specimen measured 2.4 by $0.54 \mathrm{~mm}$. In other respects they resemble L. elongatum.

6. Homalometron pallidum Staff. 1904 (Figs. 1 and 2)

From intestine, Fundulus heteroclitus.

Stafford (1904) bases this genus on the form described as Dist. sp. by Linton (1901:422). Looss $(1907: 613-14)$ points out that the trematode seems to agree with the genus Lepocreadium of Stossich (1903). The most important features of this species are found in the male reproductive system. In Lepocreadium a prominent cirrus sac is present. It encloses the prostate gland and an anterior region of the seminal vesicle which is thus divided into two parts. In the present form from Fundulus, however, the cirrus sac is entirely absent and the globular seminal vesicle opens directly into the pars prostatica the glandular cells of which lie free in the parenchyma at about the level of the ventral sucker (Fig. 2). The genital pore is median.

\section{Steganoderma formosum Staff. 1904 (Fig. 8)}

From pyloric caeca, Hippoglossus hippoglossus (Halibut).

Six specimens were obtained from the pyloric caeca of a single halibut. The genus seems to resemble Lecithostaphylus Odhner, differing in its very small pharynx, long esophagus, elongate cirrus, well developed excretory vesicle, and Laurer's canal with pore. An outline of the genus based on Stafford's description with some additions follows:

Body somewhat elongate, regular in outline, flattened, both ends rounded, anterior end slightly broader. Scale-like spines cover body to near the posterior end. Suckers about equal in size, ventral sucker a little more than $1 / 3$ from anterior end. Very small pharynx, long esophagus, caeca extending slightly more than half the body length. Ovary median or to one side, just posterior to the ventral sucker. Testes side by side at ends of caeca. Uterus between testes and filling posterior part of body. Cirrus sac elongate, almost straight, reaching posteriorly to and sometimes overlapping the ventral sucker, crossing left caecum between ventral sucker and the forking of the intestine. Genital opening ventral and to the left about half way between caecum and margin of the body. Vitellaria lateral, reaching from ventral sucker to the testes, composed of a few large follicles. Laurer's canal present. Seminal receptacle absent. Type species: S. formosum Staff.

\section{Otodistomum cestoides (van Ben. 1870)}

From stomach, Raia laevis (Barn-door skate)

Special consideration was given to this form and a careful study of its morphology, the hatching of its eggs, its miracidium, and growth 
changes was made. Certain conclusions from this study were applied to various fresh-water Azygiidae. The results of this study will appear in a later paper.

9. Hemiurus levinseni Odhner 1905

From stomach, Gadus callarias (Cod), Urophycis chuss (Squirrel hake).

The $H$. appendiculatus of Stafford described as with "suckers of equal size" probably belongs to $H$. levinseni. Eighteen specimens were taken from the stomach of six squirrel hake. Six or eight specimens were collected from three cod.

\section{Brachyphallus crenatus (Rud. 1802)}

From stomach and intestine, Osmerus mordax (Smelt), Pollachias virens (Pollack), Clupea harengris (Herring).

Lander (1904) has described this form in detail. The present material shows distinctly lobed vitellaria which are not noticeably longer than wide. The assignment of the American form to a new species by Looss (1907 a) on the basis of shape of vitellaria was not supported by study of 32 specimens which seem to agree fully with the European B. crenatus.

\section{Lecithaster gibbosus (Rud. 1802)}

From intestine, Myocephalus octodecimspinosus? (Sculpin).

The two species Lec. confusus and Lec. gibbosus are closely related. The present specimen was assigned to the latter species because of the thickness of the ovarian lobes, the length of the vitelline lobes, and because the seminal vesicle does not extend posterior to the ventral sucker.

\section{Aponurus sphaerolecithus n. sp. (Figs. 9-13)}

From stomach, Urophycis tenuis (Hake).

Two specimens of this form were obtained from the stomach of a single host. Both specimens were mature and measured 1.47 by 0.29 $\mathrm{mm}$. and 1.1 by $0.245 \mathrm{~mm}$. Posterior to the ventral sucker the body is cylindrical. It is broadly rounded at the posterior end. The cuticula is smooth and there is no tail appendage. The sucker proportion is almost exactly $1: 2$. Pre-pharynx lacking, pharynx globular, esophagus short, wide caeca reaching to posterior end of body. The unpaired excretory vesicle branches between the ovary and testes, the two lateral branches uniting dorsal to the pharynx.

The genital pore is ventral, medium, at about mid-pharynx level. A muscular sinus sac, surrounding the genital sinus, extends dorsally and posteriorly from the pore. It reaches about half-way to the ventral sucker. The genital sinus coils slightly within the sac (Fig. 9). The testes are located a short distance posterior to the ventral sucker. In 
both specimens the right testis was slightly anterior to the left. These organs are relatively smaller than in A. laguncula, the other species in the genus. The seminal vesicle is large and simple sac like in form. It extends posteriorly to near the middle of the ventral sucker. The duct of the pars prostatica leads from the ventral surface of the seminal vesicle near its anterior end, bends directly dorsally over the anterior end of the seminal vesicle, reaches to the dorsal body wall, and then bends ventrally to unite immediately with the uterus to form the genital sinus. The two ducts unite just within the posterior tip of the sinus sac. The prostate gland is free, S-shaped in lateral view, and its total length is just about equal to the length of the sinus sac.

The globular ovary is located posterior to the testes and slightly to the right. The seminal receptacle is about one-half the size of the ovary and located anterior and slightly dorsal to it. Laurer's canal is absent. The vitellaria consist of seven separate follicles posterior to the ovary. These follicles are in two groups, one of four, and one of three follicles. The largest follicles are about the size of the ovary. Cross-sections through the larger specimen give no indication that the follicles are united at any point. In spite of Looss's question, this character seems to be a distinct one, although more material will be necessary to settle the point finally. The eggs are very large and this character forms a conspicuous difference between the two species of Aponurus. Looss gives 27 by $76 \mu$ for the eggs of $A$. laguncula. Eggs in the present species measure 56 to 65 by $26 \mu$.

General measurements on two specimens are as follows:

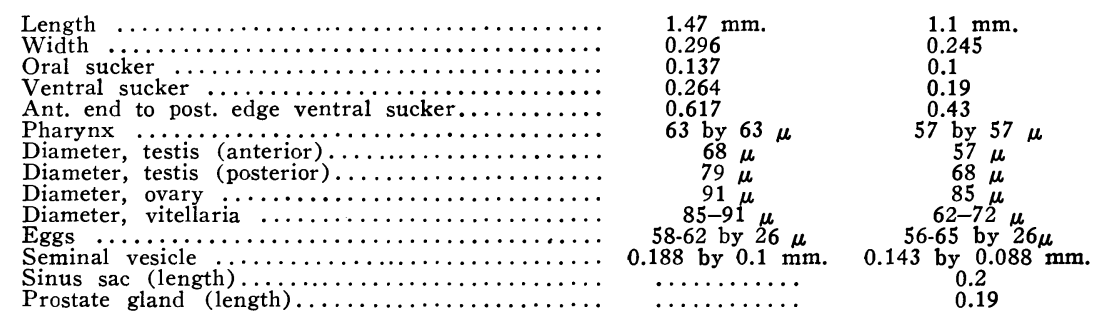

The genus Aponurus (Looss, 1907) bears close resemblance to Lecithaster and Lecithophyllum. The present form is placed in the genus Aponurus because it agrees with that genus in the following points: the genital sinus extends only half-way to the ventral sucker; the pars prostatica is about equal in length with the sinus sac; and the vitellaria are in seven separate parts. It differs from $A$. laguncula in having large eggs (as found in Lecithophyllum) and in its seminal vesicle which is simple-sac like in shape and extends slightly more posteriorly (to about the middle of the ventral sucker). 
13. Genolinea laticauda n. g., n. sp. (Figs. 3-5).

From stomach, Hippoglossus hippoglossus (Halibut).

Small, to medium-sized forms, with flattened body, tapering slightly and broadly pointed anteriorly, but broadly rounded posteriorly. Body almost uniformly wide. Cuticula smooth. Tail appendage lacking. Oral sucker embedded in body, overlapped dorsally by fleshy lip. Ventral sucker about $1 \mathrm{I} / 2$ times the size of oral sucker, located about at end of first body third. No pre-pharynx, pharynx broad, esophagus very short, caeca wide, extending to posterior tip of body. Excretory system as in other Hemiuridae, branches uniting dorsal to pharynx. Genital pore ventral, median, at about the level of the forking of the intestine. Testes globular, obliquely behind one another some distance behind ventral sucker. Ovary large, globular, behind testes. Vitellaria behind one another posterior to ovary. Uterus sends two lateral coils posterior to vitellaria to near body tip. Between the ovary and ventral sucker the uterus is in large, transverse coils. Genital sinus short, sinus sac present, pars prostatica short, seminal vesicle much coiled, just anterior or slightly overlapping the ventral sucker. Eggs 28 to 31 by 12 to $15 \mu$.

This form is most closely related to Derogenes Lühe and Genarches Lss. It differs from both in body shape which is not tapering at either end, and in position and proportional size of the ventral sucker, which is distinctly anterior to mid-body. The uterus in the present form also has a distinct course differing from both Derogenes and Genarches. The most marked difference between Genarches and Genolinea is the fact that in the former genus the two caeca of the intestine are continuous with each other posteriorly. From Derogenes, the new genus, in addition to points already mentioned, is distinct in possessing a very short prostate gland, much coiled seminal vesicle, and in a more linear arrangement of the reproductive organs.

Measurements on two specimens are as follows:
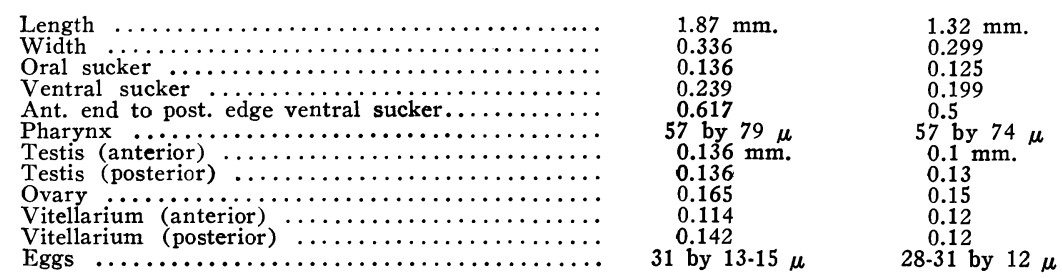

14. Gonocerca phycidis n. g., n. sp. (Figs. 6-7)

From gills, branchial cavity, and stomach, Urophycis chuss (Squirrel hake).

Body elongate, both ends bluntly rounded, cuticula smooth, body only slightly flattened, oval in $\mathrm{x}$-section, tail appendage lacking. Ventral 
sucker posterior to mid-body, almost twice as large as oral sucker, about as wide as body. Mouth opening sub-terminal, overlapped dorsally by lip-like projection of body, oral sucker embedded in body. No prepharynx, short esophagus, caeca reaching to posterior end of body. Excretory vesicle branches just posterior to the ovary, the branches uniting dorsal to the oral sucker near the anterior tip. Gonads crowded together posterior to the ventral sucker and filling most of body space in that region. Genital pore ventral, median, close behind mouth opening. Ovary median just behind ventral sucker, anterior to testes. Vitellaria unlobed, lateral and very slightly posterior to ovary. Ootype without membrane, dorsal and anterior to ovary. Laurer's canal present. Uterus entirely anterior to ovary. Eggs large. Testes large, just posterior to ovary, obliquely behind and in contact with each other. Seminal vesicle comma-shaped, pointed anteriorly, located at about the level of the pharynx. Prostate gland little developed, free, short, located ventral to the oral sucker just anterior to the seminal vesicle. Cirrus sac absent. Genital sinus short. No localized seminal receptacle. About 15 specimens were taken from the gills and branchial cavity of a single host. Two specimens were obtained from the stomach.

Gonocerca shows resemblance to Liocerca Lss. which is also a gill parasite and one of the few Hemiurids with testes posterior to the ovary. Hemipera Nicoll (1913) also shows this feature. A tabular comparison of the three genera follows :

\begin{tabular}{|c|c|c|c|}
\hline & Liocerca & Gonocerca & Hemipera \\
\hline Habitat & Gills & Gills & Stomach \\
\hline $\begin{array}{l}\text { Position of genital } \\
\text { pore }\end{array}$ & $\begin{array}{l}\text { Somewhat distant } \\
\text { from oral sucker }\end{array}$ & $\begin{array}{l}\text { Close to oral } \\
\text { sucker }\end{array}$ & $\begin{array}{l}\text { Somewhat distant } \\
\text { from oral sucker }\end{array}$ \\
\hline $\begin{array}{l}\text { Position of ven- } \\
\text { tral sucker }\end{array}$ & About mid-body & $\begin{array}{l}\text { Posterior to mid- } \\
\text { body }\end{array}$ & $\begin{array}{l}\text { Posterior to mid- } \\
\text { body }\end{array}$ \\
\hline Testes & $\begin{array}{l}\text { Behind one } \\
\text { another }\end{array}$ & $\begin{array}{l}\text { Behind one } \\
\text { another }\end{array}$ & $\begin{array}{l}\text { Lateral to each } \\
\text { other }\end{array}$ \\
\hline Cirrus sac & $\begin{array}{l}\text { Inclosing on } 1 \mathrm{y} \\
\text { male duct }\end{array}$ & Absent & $\begin{array}{l}\text { Inclosing prostate } \\
\text { gland and sem. } \\
\text { vesicle }\end{array}$ \\
\hline $\begin{array}{l}\text { Prostate gland } \\
\text { Seminal vesicle }\end{array}$ & $\begin{array}{l}\text { Free, elongate } \\
\text { Near ventra } 1 \\
\text { sucker }\end{array}$ & $\begin{array}{l}\text { Free, short } \\
\text { Near pharynx }\end{array}$ & $\begin{array}{l}\text { Inclosed } \\
\text { Between suckers }\end{array}$ \\
\hline ggs & $\begin{array}{l}\text { Non-filamented, } \\
\text { numerous }\end{array}$ & $\begin{array}{l}\text { Non-filamented } \\
\text { numerous }\end{array}$ & Filamented, few \\
\hline
\end{tabular}

Form, shape, size, cuticula, excretory and digestive systems are similar in all three genera.

Meaurements on five specimens of Gonocerca phyridis are as follows :

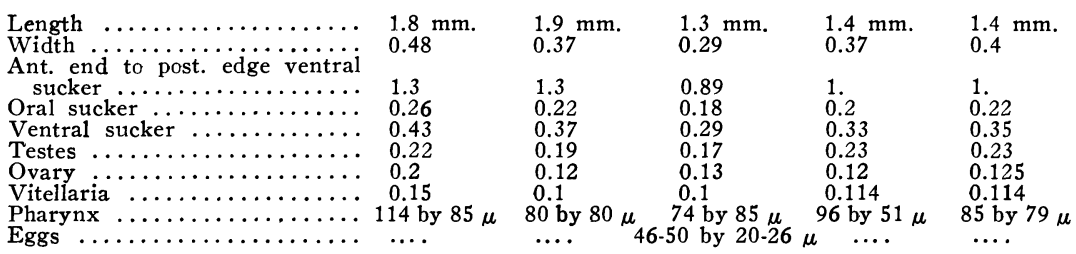




\section{Derogenes varicus (Müller 1784)}

From stomach, Gadus callarias (Cod), Urophycis tenuis (Hake), Urophycis chuss (Squirrel hake), Anarrhichas lupus (Wolf-fish), intestine, Hippoglossus hippoglossus (Halibut), Myxocephalus octodecimspinosus (Sculpin).

\section{Acanthocotyle verrilli Goto 1899}

From body surface, Raia erinacea (Bonnet skate).

A single specimen of this species was collected. The species is described by Goto (1899) from a single specimen sent him by Verrill who obtained it from the surface of a "skate" (from Cape Cod).

Monticelli (1904:73-74) insists that the anterior "invaginations" of Goto are true suckers, and this conclusion is supported by study of the specimen at hand. Goto was also in error (as Monticelli suggests) in respect to the genital openings which are three in number as in other species of the genus. Monticelli also believes Goto wrong in regard to the metraterm opening to the right. In the present specimen there is no doubt, however, that this pore is on the right side. This condition may, of course, represent a case of amphitypy.

\section{Dactylocotyle minor (Olss. 1868)}

From gills, Urophycis chuss (Squirrel hake).

Three specimens were collected from the gills of a single fish, but the parasite is not common. It cannot be referred to Dact. phycidis because of its marked difference in size, shape, and number of hooks in the genital sucker. The live worms are of a gray color. There are 14 hooks in the genital sucker. A single nonfilamented egg in the vagina measured 159 by $17 \mu$. There is a common genital opening.

\section{Literature Cited}

Cooper, A. R. 1915.-Trematodes from Marine and Freshwater Fishes, including one Species of Ectoparasitic Turbellarian. Trans. Roy. Soc. Canad., Sec. IV, $9: 181-205,3$ pls.

Goto, S. 1899.-Notes on Some Exotic Species of Ectoparasitic Trematodes. Jour. Sci. Coll. Imp. Univ. Tokyo, 12:263-295, pls. 20-21.

Lander, C. H. 1904.-The Anatomy of Hemiurus crenatus (Rud.) Lühe, an Appendiculate Trematode. Bull. Mus. Comp. Zool. Harv. College, 45 : 1-28, 4 pls.

Lebour, M. V. 1908.-Fish Trematodes of the Northumberland Coast. Rept. Northumberland Sea Fish. for 1907, 3:3-47, 5 pls.

Linton, E. 1898.- Notes on Trematode Parasites of Fishes. Proc. U. S. Nat. Mus., $20: 507-548$, pls. 40-54.

1901.-Parasites of Fishes of the Woods Hole Region. Bull. U. S. Fish Comm. for 1899, 19:405-492, 34 pls.

Looss, A. 1907.-Zur Kenntnis der Distomenfamilie Hemiuridae. Zool. Anz., $31: 585-620$

1907 a.-Beiträge zur Systematik der Distomen. Zool. Jahrb., Syst., 26 : 63-180, Taf. 7-15. 
Monticelli, F. S. 1904.-Osservazioni intorno ad alcune specie di Heterocotylea. Boll. Soc. nat. Napoli, 18:65-80, 5 text figs.

Nicoll, Wm. 1913.-New Trematode Parasites from Fishes of the English Channel. Parasit., 5:238-246, pl. 11.

1913 a.-Trematode Parasites from Food-fishes of the North Sea. Parasit., $6: 188-194$, pl. 13 .

Odhner, T. 1905.-Trematoden des arktischen Gebietes. Fauna Arctica, 4:291-372, 4 text figs., Taf. 2-4.

Stafford, J. 1904.-Trematodes from Canadian Fishes. Zool. Anz., 27: 481-495.

Stossich, M. 1903.-Note distomologiche. Boll. Soc. adr. sci. nat. Trieste, $21: 193-201$.

Explanation of Plate II

All drawings were made with the aid of a camera lucida, and the projected scale has the value of $0.1 \mathrm{~mm}$.

Abbreviations : $c s$, cirrus sac; $d p$, duct of prostate gland; $e$, excretory system; $e s$, esophagus ; $g p$, genital pore; $g s$, genital sinus ; $l c$, Laurer's canal; $o$, ovary; $o v$, ovum; $p r$, prostate gland; $s r$, seminal receptacle; $s s$, sinus sac; $s v$, seminal vesicle; $t$, testis; $u$, uterus ; $v$, vagina ; $v t$, vitellaria ; $y d$, yolk duct.

Fig. 1.-Homalometron pallidum. Ventral view.

Fig. 2.-H. pallidum. Sagittal section through region of seminal vesicle.

Fig. 3.-Genolinea laticauda. Ventral view of anterior body region.

Fig. 4.-Ventral view of entire body of G. laticauda.

Fig. 5.-Same, of another specimen.

Fig. 6.-Gonocerca phycidis. Ventral view.

Fig. 7.-Ventral view of anterior body region of same.

Fig. 8.-Steganoderma formosum. Ventral view.

Fig. 9.-Lateral view of anterior body region of Aponurus Sphaerolecithus.

Fig. 10.-Ventral view of entire body of $A$. Sphaerolecithus.

Fig. 11.-Cross-section through body of $A$. Sphaerolecithus just posterior to sinus sac.

Fig. 12.-Ventro-lateral view of body of $A$. Sphaerolecithus in region of gonads.

Fig. 13.-Ventral view of same region. 


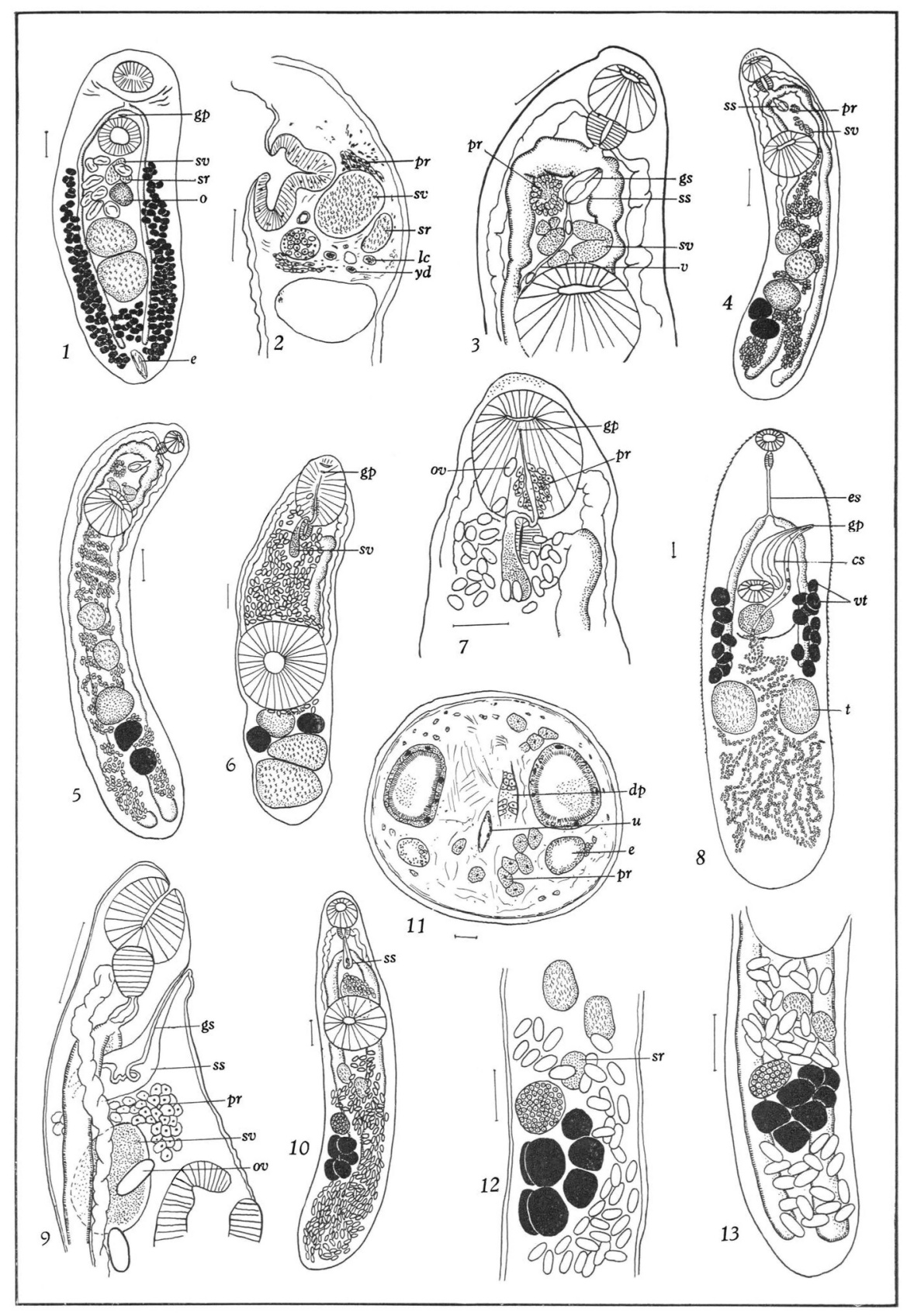

PLATE II 